\title{
CEO COMPENSATION AND FIRM PERFORMANCE IN JAPAN: EVIDENCE FROM NEW PANEL DATA ON INDIVIDUAL CEO PAY*
}

\author{
by
}

Takao Kato and Katsuyuki Kubo**

April 2003

\begin{abstract}
$\underline{\text { ABSTRACT }}$
Prior studies on Japanese executive compensation have been constrained by the lack of longitudinal data on individual CEO pay. Using unique 10-year panel data on individual CEO's salary and bonus of Japanese firms from 1986 to 1995, we present the first estimates on the performance sensitivity of Japanese CEO compensation. Specifically we find consistently that Japanese CEO's cash compensation is sensitive to firm performance (especially accounting measures), and that the sensitivity of CEO's cash compensation to ROA is 1.3 to 1.4 , which is in general agreement with prior estimates elsewhere. As such, our estimates do not support that Japanese corporate governance is unusually defunct with regard to the significance and size of the sensitivity of CEO compensation to accounting profitability. On the other hand, to be consistent with the literature on Japanese corporate governance that tends to downplay the role of shareholders and stress the role of banks and employees, we find that stock market performance tends to play a less important role in the determination of Japanese CEO compensation. Finally, we find that the bonus system makes CEO compensation more sensitive to firm performance in Japan. The finding is in contrast to the literature on compensation for regular employees in Japan which often argues that bonus is a disguised base wage.
\end{abstract}

JEL: M12, M52, J33, G30, 053

Keywords: CEO compensation, executive compensation, corporate governance, and Japan.

Correspondence: Takao Kato, Professor and Presidential Scholar Department of Economics, Colgate University, Hamilton, NY 13346

Phone: 315-228-7562 Fax: 315-228-7033

Internet: tkato@mail.colgate.edu

* The authors are grateful to a major compensation consulting company for providing the data for this study.

** Takao Kato is Professor of Economics and Presidential Scholar at Colgate University; Research Associate, Center on Japanese Economy and Business at Columbia University; and Research Associate, Tokyo Center for Economic Research. Katsuyuki Kubo is Lecturer at Institute of Economic Research, Hitotsubashi University. 


\section{CEO COMPENSATION AND FIRM PERFORMANCE IN JAPAN: EVIDENCE FROM NEW PANEL DATA ON INDIVIDUAL CEO PAY}

\section{Introduction}

CEO compensation of U.S. corporations has been studied extensively in the last two decades. ${ }^{1} \quad$ In contrast, few attempts have been made to study CEO compensation of Japanese firms. ${ }^{2} \quad$ Unlike in the U.S., Japanese firms have not been required to disclose information on compensation for any individual executives, and hence compensation data on individual executives of Japanese corporations have not been available for researchers. The lack of such individual compensation data has been forcing researchers to tap into an alternative aggregate data source.

Though not required to report salary and bonus of CEOs, Japanese corporations are required to report total salary and bonus earned by all directors, and such aggregate executive compensation data are readily available annually over an extended period of time. ${ }^{3}$ Prior studies often use a directory of corporate executives (such as Yakuin Shikiho) to obtain the total number of directors for each publicly traded firm in Japan and calculate the average director's pay by dividing the total salary and bonus of all directors by the total number of directors. ${ }^{4}$ The data are, however, subject to usual aggregation bias: changes in the composition of the board will affect the salary and bonus earned by all directors. In addition, they are subject to rather substantial underreporting of the salary and bonus earned by the average full-time director.

First, in Japanese publicly held corporations, the heads (typically called "Bucho") of

\footnotetext{
1 A number of excellent surveys on this literature are available. See, for example, Murphy (1999) for the mostly empirical literature and Gibbons and Waldman (1999) for the largely theoretical literature. For an authoritative survey of earlier work, see Rosen (1990) who concludes his survey by urging scholars to broaden their inquiry beyond the U.S. to other countries, in particular Japan.

2 Japanese CEOs (Shacho or Todori in the case of banks) are typically the most powerful and highest-ranking member of the board of directors although occasionally retired CEOs continue to have strong influence on the board as Kaicho. We do not have individual compensation data on Kaicho.

${ }^{3}$ Nikkei NEEDS database is perhaps the most convenient way to get these panel data.

4 See, for instance, Kaplan (1994), Xu (1997), Ang and Constand (1997), Joh (1999) and Kubo (2001).
} 
major functional departments such as marketing, accounting, and personnel, are often appointed as directors. Nonetheless, a large fraction of their salary is paid as wage payments for employees and is not reported as the salary and bonus of all directors in corporate proxy statements. According to the Survey on Executive Compensation, Reward, and Pensions conducted in 1988 by Romu Gyosei Kenkyu Jo (Human Resource Management Research Institute), for those directors who are also the heads of departments, on average, only one third of the total compensation is reported as executive compensation in corporate proxy statements and the remaining two thirds are paid as "wage payment". Romu Gyosei Kenkyu Jo (1988: 16) estimates that the inclusion of such "wage payment" will increase the average salary and bonus of all directors by more than $20 \%$.

Second, the total salary and bonus data reported in corporate proxy statements include part-time directors. According to the Survey on Executive Compensation, Reward, and Pensions, the average part-time director earns about one quarter of what their full-time counterparts earn (see, Romu Gyosei Kenkyu Jo, 1988: 14). Moreover, the same survey shows that more than $80 \%$ of firms with 1,000 or more employees have such part-time directors and among those firms with part-time directors, the average board of directors includes 2.5 part-time directors. Since the same survey reports that the average board includes 19.2 full-time directors, the part-time directorship is hardly negligible. The inclusion of those part-time directors will significantly lower the average salary and bonus of all directors. ${ }^{5}$

This paper fills an important gap in the literature by providing the first econometric evidence on the performance sensitivity of Japanese CEO's cash compensation, using unique panel data on individual CEO compensation of Japanese firms. In so doing, the paper

5 See Kato (1997) for more details. Kato and Rockel (1992a) collected individual tax returns of CEOs of 599 leading corporations in Japan and estimated each CEO's taxable income. They then estimated pay-performance sensitivities cross-sectionally. Unfortunately, the cross-sectional nature of the data did not allow for standard fixed effect estimates. 
contributes to one of the most important recent public-policy debates in Japan, or corporate governance reform. ${ }^{6}$

The proponents of such reform argue that Japanese corporate governance is not sufficiently oriented towards shareholders and recommend changes that will bring Japanese corporate governance more in line with the Anglo-American model. In fact, some of their recommendations have been already implemented. ${ }^{7}$ Unfortunately, however, existing evidence on the nature of managerial incentives in Japanese firms is limited and mixed. In particular, there is no systematic study to investigate the performance sensitivity of Japanese CEO compensation using panel data on individual CEO compensation. Even those studies using aggregate data tend to report mixed evidence (Kubo, 2001; 6). The present study provides the first systematic evidence on the performance sensitivity of Japanese CEO compensation and thus offers important information currently missing in the debate.

Specifically, we find consistently for all specifications that Japanese CEO's cash compensation is indeed sensitive to firm performance (especially accounting measures as opposed to stock market measures), and that the sensitivity of CEO's cash compensation to ROA (Return On Asset) is 1.3 to 1.4, which is in general agreement with prior estimates elsewhere. Our estimates do not support that Japanese corporate governance is unusually defunct with regard to the significance and size of the sensitivity of CEO compensation to accounting profitability. ${ }^{8}$ On the other hand, we do find that stock market performance tends to play a less important role in the determination of Japanese CEO compensation, which is largely consistent with the literature on Japanese corporate governance that tends to downplay the role of shareholders and stress the interests of banks and employees. Finally,

\footnotetext{
${ }^{6}$ See, for example, Ahmadjian (2001) for the debate on corporate governance reform in Japan.

7 Stock options have been legalized in 1997 in Japan and since then they have been spreading rather rapidly. See, for instance, Nagaoka (2002) for the recent diffusion of stock options among Japanese firms.

${ }^{8}$ In addition, prior studies provide evidence for executive turnover as a significant incentive mechanism to make Japanese executives responsive to firm performance. See, for example, Kaplan and Minton (1994), Abe (1997), and Morck and Nakamura (1999).
} 
we find that the bonus system makes CEO compensation more sensitive to firm performance in Japan. The finding is in contrast to the literature on compensation for regular employees in Japan which often argues that bonus is a disguised base wage.

In the next section we begin with background information on Japanese CEOs and corporate governance, and then introduce the data and describe our empirical strategy in Section III. The results are presented in Section IV, followed by a concluding section.

\section{Japanese CEOs and Corporate Governance}

Kato and Rockel (1992b) assembled for the first time a large cross-national micro data set, containing information on CEOs of the 1000 most valuable (measured by market equity value) firms in Japan as well as information on CEOs of the 1000 most valuable firms in the U.S. They find that over 60 percent of Japanese CEOs had 15 or more years of tenure at appointment to CEO rank and that the average Japanese CEO joined the company at age 29, spent 27 years in the company, and was promoted to CEO rank at age 56. For the U.S., they discover that close to 50 percent of CEOs had 15 or more years of tenure at appointment to CEO rank and that the average CEO joined the firm at age 29, spent 20 years in the firm, and was promoted to CEO rank at age 49. As such, the internal labor market for managers is quite well developed in both nations but it appears to play a more important role in the selection of CEOs in Japan than in the U.S.

In terms of educational credentials, Kato and Rockel (1992b) report that as expected, nearly all CEOs (95 percent for Japan and 97 percent for the U.S.) hold college degrees. The highest proportion (close to 30 percent) of Japanese CEOs earned their degrees from the University of Tokyo and the most common major was economics and business (36 percent of Japanese CEOs majored in these subjects). The highest proportion (a little over 10 percent) 
of U.S. CEOs received their highest degrees from Harvard and one in five earned the degree of M.B.A.

In spite of a popular belief of "underpaid" Japanese CEOs (or "overpaid" U.S. CEOs), there are only a few estimates on the level of Japanese CEO compensation. Romu Gyosei Kenkyu Jo (1984) uses responses of 38 Japanese firms with 10 billion yen or more paid-in capital to a survey conducted by Chingin Kanri Kenkyu Jo (Wage Management Research Institute), and reports that the mean salary and bonus of CEOs in 1983 is 41 millions of yen (roughly 122 thousand dollars). A more recent estimate is reported by Romu Gyosei Kenkyu Jo (1988). Using responses of 45 Japanese firms with 1,000 or more employees to a survey conducted by Romu Gyosei Kenkyu Jo, they estimate the mean salary and bonus of CEOs in 1988 to be 35 millions of yen (roughly 276 thousand dollars). The estimate based on the largest number of firms (599 publicly-traded firms in Japan) is provided by Kato and Rockel (1992a). They use individual income tax returns of each CEO of these 599 firms, and report that the average taxable income of these CEOs in 1985 is about 44 millions of yen (roughly 220,000 dollars).

Institutional information on who sets CEO compensation and how it is set is relatively scarce. ${ }^{9}$ The literature suggests that like in the U.S., initial recommendations for director's pay levels (including CEO's) typically originate from the firm's management team. ${ }^{10}$ In large U.S. corporations, however, such recommendations will need to be approved by the firm's compensation committee consisting of two or more "outside" directors. Though such compensation committees are not completely free from CEO influence, they are not entirely entrenched and do function as a somewhat effective corporate governance mechanism in the U.S. (Murphy, 1999) Such compensation committees are not typically used in Japan.

\footnotetext{
${ }^{9}$ For such institutional information, see, for example, Murphy (1999) for the U.S. and Matsumoto (1991), Fukao (1995), and Kubo (2001) for Japan.

${ }^{10}$ While recommendations in the U.S. are for actual pay levels, those in Japan are for the maximum pay levels and typically the actual pay levels are less than the maximum levels (Kubo, 2001).
} 
Instead, recommendations for director's pay levels (that are typically proposed by directors themselves) are usually rubber-stamped by the annual general meetings of shareholders (Kubo, 2001). As a result, it is often hypothesized that the sensitivity of CEO compensation to firm performance, in particular stock market performance, is weak in Japan.

In addition, the literature on Japanese corporate governance tends to suggest that the market for corporate control, or the takeover disciplines may not be an effective mechanism for monitoring and controlling the behavior of CEOs and other senior directors in Japan. ${ }^{11}$ First, the board of directors of Japanese corporations "functions as a de facto substructure of the management system subordinate to the representative (and permanent) directors (Aoki, 1988: 142-149)." Second, as discussed above, the annual general meetings of shareholders tend to be a mere formality. Finally, takeovers in Japan are likely to entail prohibitively high cost of internal reorganizations of the Japanese company with well developed internal labor markets, resulting in making takeovers an empty threat.

The literature then often points to the main bank as a more effective alternative corporate governance mechanism in Japan. Specifically, the main bank as the principal lender gather and analyze vital information on its member firms (of which it is the principal lender) regularly and send its representatives to their boards when necessary.

In short, the interests of shareholders are somewhat diluted in the Japanese corporate governance system as a result of the strong presence of the interests of other constituencies (e.g., debtholders and employees) in the Japanese corporate governance system. The diluted interests of shareholders in the Japanese corporate governance imply that the sensitivity of CEO pay to firm performance, in particular stock market performance, may be weakened in Japan.

${ }^{11}$ See for example Aoki (1988), Sheard (1989), Hoshi, Kashyap, Scharfstein (1990 and 1991), Kaplan and Minton (1994), Montalvo and Yafeh (1994), Aoki and Patrick (1994), Weinstein and Yafeh (1995, 1998), Kato (1997), and Morck and Nakamura (1999). 


\section{Data and Empirical Strategy}

A major compensation consulting firm provided us with a 10-year panel data on salary and bonus of CEOs of 51 Japanese firms (18 listed and 33 unlisted firms) from 1986-1995. The data were from a private survey of CEO compensation conducted annually between 1986 and 1995 by the consulting firm. ${ }^{12}$ The industrial makeup of the sample of 51 firms is $48 \%$ manufacturing; $21 \%$ retail and wholesale trade; $12 \%$ services; $8 \%$ construction; and the rest are equally split between Transportation/communication (6\%) and finance/insurance (6\%). The Establishment and Enterprise Census conducted since 1947 by Japan Statistical Bureau provide the industrial makeup of the population of all firms in Japan. ${ }^{13}$ The corresponding figures for the population of all firms in Japan in 1996 were $20 \%$ manufacturing; $36 \%$ retail and wholesale trade; $15 \%$ services; $18 \%$ construction; $3 \%$ Transportation/communication; and 1\% finance/insurance (and about $7 \%$ all other industries, such as agriculture, mining, and real estate). It follows that manufacturing, transportation/communication, and finance/insurance are overrepresented in our sample.

To further shed light on the nature of our sample firms as compared to the population of all Japanese firms, Figure 1 compares average ROA (a standard accounting measure of firm performance) between our sample firms and all Japanese firms over the sample period. The average ROA of all Japanese firms is calculated using Financial Statements Statistics of Corporations published every year by Japan Ministry of Finance. Figure 1 shows that movement of ROA over the sample period is remarkably similar between our sample firms and the population of all firms in Japan although our sample firms have outperformed the population of all firms in Japan consistently throughout the period.

Finally, for listed firms, using Nikkei NEEDS database, we calculated average

12 The use of such propriety data is not an uncommon practice in the literature. See, for example, Leonard (1990), Abowd (1990), Brunello, Eriksson (1999), Graziano and Parigi (2001), and Eriksson (2003).

${ }^{13}$ It was conducted every five years since 1981 and the 1996 census turns out to be the closest to the end year of our sample (1995). 
annual shareholder return (ROR) over the sample period for our sample firms as well as for all listed firms in Japan. Figure 2 shows both series. Reassuringly movement of ROR over the sample period is again similar between our sample firms and the population of all listed firms.

To study the performance sensitivity of Japanese CEO compensation, we begin with a standard executive compensation equation. ${ }^{14}$ That is,

$$
\Delta \ln (\text { APAY })_{\mathrm{it}}=\mathrm{f}\left(\text { PERFORMANCE }_{\mathrm{it}}\right)
$$

where APAY=annual cash compensation of CEO of Firm i in Year $t$; and PERFORMANCE $\mathrm{it}_{\mathrm{it}}=$ performance of Firm $\mathrm{i}$ in Year t. $\Delta \ln (\mathrm{APAY})_{\mathrm{it}}$ is annual rate of growth of APAY. In short, Eq. (1) simply states that CEO's annual pay growth depends on his/her firm's performance. For PERFORMANCE $E_{i t}$, prior studies generally consider three types of measures: (i) accounting performance variables, such as changes in ROA (Return On Asset) and incidence of a negative profit; (ii) stock market performance variables, typically shareholder return; and (iii) sales growth. In this paper, our data allow us to consider the following four variables: (i) $\mathrm{DROA}_{i t}$ (changes in ROA of Firm i from Year t-1 to Year t; (ii) NEGPROF $_{\text {it }}\left(=1\right.$ if Firm i's pre-tax profit is negative in Year t, 0 otherwise); (iii) ROR $_{\text {it }}$

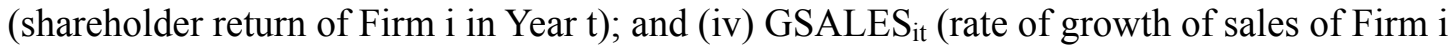
from Year $\mathrm{t}-1$ to Year $\mathrm{t}$ ). Since we can obtain stock market data for only listed firms, $\mathrm{ROR}_{\mathrm{it}}$ is used only when we restrict our sample to listed firms.

We begin with each performance variable individually and then consider all of them together. That is, for all firms including both listed and unlisted firms, we estimate:

$$
\begin{aligned}
& \Delta \ln (\text { APAY })_{i t}=\alpha+\beta_{\mathrm{d}} \text { DROA }_{i t}+u_{i t} \\
& \Delta \ln (\text { APAY })_{i t}=\alpha+\beta_{\mathrm{n}} \text { NEGPROF }_{i t}+u_{i t} \\
& \Delta \ln (\text { APAY })_{i t}=\alpha+\beta_{\mathrm{g}} \text { GSALES }_{i t}+u_{i t}
\end{aligned}
$$

\footnotetext{
14 See, for example, Murphy (1998).
} 


$$
\Delta \ln (\text { APAY })_{i t}=\alpha+\beta_{\mathrm{d}} \mathrm{DROA}_{i \mathrm{t}}+\beta_{\mathrm{n}} \mathrm{NEGPROF}_{\mathrm{it}}+\beta_{\mathrm{g}} \mathrm{GSALES}_{\mathrm{it}}+\mathrm{u}_{\mathrm{it}}
$$

Our sample includes both listed and unlisted firms. Conceivably the public nature of listed firms makes them more responsive to the interests of shareholders and hence makes their CEO compensation more sensitive to publicly observable profitability measures, such as ROR and ROA. ${ }^{15}$ To see if listed firms and unlisted firms differ in the way of paying their CEOs, we split our sample into the listed sample consisting of only listed firms and the unlisted sample consisting of only unlisted firms. Furthermore, for listed firms, stock market data are readily available and therefore shareholder return (ROR) can be considered. Finally, all prior studies on Japanese executive compensation focus on listed firms.

Obtaining separate estimates for listed firms and unlisted firms, we can provide the first econometric evidence on the determinants of executive compensation of unlisted firms in Japan whereas our listed firm estimates can be compared to those obtained by prior studies, all of which use aggregate data for listed firms.

Specifically, for the unlisted sample, we re-estimate the same equations whereas for the listed sample, we add:

$$
\Delta \ln (\text { APAY })_{\mathrm{it}}=\alpha+\beta_{\mathrm{r}} \mathrm{ROR}_{\mathrm{it}}+\mathrm{u}_{\mathrm{it}} \text {; and }
$$

replace Eq. (5) with:

$$
\Delta \ln (\text { APAY })_{\mathrm{it}}=\alpha+\beta_{\mathrm{d}} \text { DROA }_{\mathrm{it}}+\beta_{\mathrm{n}} \mathrm{NEGPROF}_{\mathrm{it}}+\beta_{\mathrm{g}} \mathrm{GSALES}_{\mathrm{it}}+\beta_{\mathrm{r}} \mathrm{ROR}_{\mathrm{it}}+\mathrm{u}_{\mathrm{it}}
$$

$\mathrm{APAY}_{\text {it }}$ is calculated by adding annual bonus to 12 times CEO's monthly salary, and does not include non-cash compensation, such as stock options, deferred compensation and perquisites. No micro data of Japanese CEO compensation (including the one used in this paper) provides information on such non-cash compensation. However, the omission of these less visible forms of CEO compensation may not pose as serious a problem as in the case of the U.S. Except for perquisites, over the time period under consideration, these

${ }^{15}$ Brunello, Graziano and Parigi (2001) test a similar hypothesis for a sample of Italian firms and find that pay-performance sensitivity is indeed higher in listed firms than in unlisted firms. 
forms of compensation were probably not as wide-spread in Japan as in the U.S. ${ }^{16}$ Even if the considerable amount of these less visible forms of compensation are present, the neglect of these forms of compensation would not be a problem insofar as movements in these forms of compensation and cash compensation are correlated (Kaplan, 1994).

We also estimate each equation with and without year effects to see if controlling for time-specific shocks that are common to all firms change the results.

Finally, we repeat the same analysis using CEO's monthly base salary MPAY it instead of his/her total annual cash compensation which includes both base salary and bonus. ${ }^{17}$ The Japanese bonus payment system has attracted considerable attention and controversy, in particular the debate between those who stress that the bonus system makes the Japanese payment system more sensitive to firm performance (especially profitability) and those who argue that bonus is simply a disguised regular wage and that it is introduced largely for tax advantages. ${ }^{18}$ We contribute to the debate by testing whether the Japanese bonus system makes CEO compensation more sensitive to firm performance. ${ }^{19}$

Descriptive statistics for key variables are summarized in Table 1, where all value variables are in 2000 yen. Over the sample period of 1986-1995 the average CEO earned 28 millions of yen a year and his/her monthly base salary was 2 millions of yen. Listed firms tend to pay their CEOs more than unlisted firms (33 millions of yen vs. 26 millions of yen for APAY and 2.4 millions vs. 1.9 millions for MPAY). The average annual pay increase of all CEOs was 480 thousands of yen in real terms over the sample period. There appeared to be a large gap in the pay increase between listed and unlisted firms (950 thousands of yen vs.

\footnotetext{
16 See Kato (1997) for more details.

17 We also repeated the same analysis using CEO's annual bonus. Unfortunately, we lost a significant number of observations with BONUS $=0$ (and therefore log of BONUS undefined), and our estimates turned out to be quite imprecise.

${ }_{18}$ For the debate, see for example Freeman and Weitzman (1987), Ohashi (1989), Hashimoto (1990), Brunello (1991), and Hart and Kawasaki (1999).

${ }^{19} \mathrm{Xu}$ (1977) and Kubo (2001) use aggregate data on directors' pay and test a similar hypothesis.
} 
220 thousands of yen). A similar pattern is observed for CEO's monthly base salary increase as well.

The average sales of our sample firms were 44 billions of yen and the average annual growth of sales (in real terms) was 3.5 percent. As expected, sales were greater for listed firms than for unlisted firms (62 billions of yen vs. 30 billions of yen). However, sales grew somewhat less rapidly for listed firms than for unlisted firms (3.2 vs. 3.7). Our sample firms on average made a pre-tax profit of 1.9 billions of yen, and enjoyed ROA of 4.4 percent. Listed firms earned over six times more profit than unlisted firms whereas ROA is 4.7 percent for listed firms and 4.2 percent for unlisted firms. The average likelihood of making a negative profit was about 8 percent for all firms. Listed firms are less likely to make a negative profit than unlisted firms (6.6 vs. 8.7). The average employment level of our sample firms was a little over 700 employees. Not surprisingly, on average listed firms employ more workers than unlisted firms (1355 vs. 368). Finally, the data show a slight fall in ROA on average each year over the sample period (0.07 percentage-point fall). List firms experienced a greater fall ( 0.19 percentage-point fall) whereas unlisted firms enjoyed a slight increase (0.007 percentage-point increase).

\section{$\underline{\text { VI. Results }}$}

Table 2 presents the OLS estimates of Eq. (2)-Eq. (5) with and without year effects, using our full sample of firms including both listed and unlisted firms. When only ROA (a standard accounting performance measure) is considered, the estimated coefficient on DROA is 1.415 and statistically significant at the 1 percent level. The positive and significant sensitivity of CEO's annual cash compensation to ROA does not change even if we include the year dummy variables although the size of the pay-performance sensitivity falls 
somewhat to 1.391. It follows that a 1 percentage-point increase in ROA (say, 0.04 to 0.05 ) will lead to a 1.391-percent increase in CEO's annual cash compensation. Since the average CEO earns 28 millions of 2000-constant yen, improving ROA by 1 percentage point on average results in an increase in annual cash compensation of 0.38 millions of 2000 -constant yen.

In Eq. (3) and Eq. (3)', we test whether CEO's annual cash compensation is sensitive to the presence of a negative profit. Regardless of the presence of the year dummy variables, the estimated coefficients on NEGPROF are negative and statistically significant at the 1 percent level. The size of the estimates implies that CEO's annual cash compensation will be reduced by 9 percent (or 2.5 millions of 2000-constant yen on average) if his/her firm makes a negative profit.

As Eq. (4) and Eq. (4)' show, the estimated coefficient on GSALES is positive and statistically significant at the 1 percent level with the year dummy variables and at the 5 percent with the year dummy variables. It implies that a 1-percentage point increase in sales growth (say, from 0.03 to 0.04 ) leads to a modest 0.14 to 0.15 percent increase in CEO's annual cash compensation (or an increase of 0.04 millions of 2000-constant yen on average).

Finally, Eq. (5) and Eq. (5)' show the estimates on the performance sensitivity of CEO's annual cash compensation when all performance variables are considered simultaneously. ROA proves to have the most robust effect on CEO's annual cash compensation. The estimated coefficients on DROA continue to be positive and statistically significant at the 1 percent level with and without the year dummy variables. The size of the estimated coefficients is somewhat smaller than when only ROA is considered. The presence of a negative profit turns out to be still negative and statistically significant at the 5 percent level with and without the year dummy variable, and the size of its effect on CEO 
annual cash compensation is a 6-percent fall instead of 9-percent fall. Sales growth is no longer significant.

We now turn to our OLS estimates for two sub-samples: (i) the listed sample; and (ii) the unlisted sample. Table 3 shows the OLS estimates of Eqs. (2), (3), (4), (6) and (7) with and without the year dummy variables for the listed sample. The estimated coefficients on DROA continue to be positive and significant at the 1 percent level with and without the year dummy variables as well as with and without other performance variables. The estimated size of the performance sensitivity of CEO's annual cash compensation is actually larger than in the case of the full sample. The estimated coefficients on NEGPROF continues to be negative and statistically significant for all specifications. The estimated coefficients on GSALES are still positive yet no longer statistically significant for all specifications.

For listed firms, stock market data are readily available. We estimated the sensitivity of Japanese CEO's annual cash compensation to shareholder return (ROR). When only ROR is considered, the estimated coefficient on ROR is positive and significant at the 1 percent level without the year dummy variables. The size of the sensitivity of CEO's annual cash compensation to shareholder return is 0.092 . This means that a 1-percentage point increase in shareholder return (say, from 0.05 to 0.06 ) will result in a 0.092 percent rise in CEO's annual cash compensation (or an increase of about 0.03 millions of 2000-constant yen on average). However, when the year dummy variables are included, the estimated coefficient on ROR falls to 0.07 and is not quite significant at the 10 percent level. For the fully nested specification of Eq. (7) and Eq. (7)', ROR is definitely insignificant at the 10 percent level with and without the year dummy variables. ${ }^{20}$

Table 4 presents the OLS estimates of Eq. (2)-Eq. (5) with and without the year

${ }^{20}$ Kaplan (1994) also finds in his regressions of the total salary and bonus earned by all directors on performance that ROR is not significant when all other performance variables are included. 
dummy variables for the unlisted sample. The estimated coefficients on DROA are again positive and significant at the 1 percent level with and without the year dummy variables as well as with and without other performance variables. The estimated size of the performance sensitivity of CEO's annual cash compensation of unlisted firms is smaller than that of listed firms, confirming our prior expectation. On the other hand, annual cash compensation of CEOs of unlisted firms are just as sensitive to the presence of a negative profit as those of listed firms. In stark contrast to CEOs of listed firms, however, for unlisted firms the estimated coefficients on GSALES are positive AND SIGNIFICANT at the 1 percent level with and without the year dummy variables when only GSALES is considered. It appears that compared to listed firms, unlisted firms tend to reward their CEOs more for their sales growth and less for ROA. Making a negative profit seems to be damaging for CEO compensation equally for both listed and unlisted firms.

Finally, we repeat the same analysis using CEO's monthly base salary instead of their annual cash compensation which include both base salary and bonus. The results are presented in Tables 5-7. For all firms, comparing Table 5 to Table 2, we discern that ROA is still a significant determinant of CEO's monthly base salary yet that the size of the effect of ROA is considerably smaller for monthly base salary than for total cash compensation. In addition, CEO's monthly base salary will be reduced as a result of a negative profit. Yet again the impact of the negative profit is smaller for monthly base salary than for total annual cash compensation. Sales growth is no longer significant with the year dummy variables even when other performance variables are excluded. The size of the sales growth effect is also substantially smaller for monthly base salary than for total annual cash compensation. Overall, our estimates show that base salary is less sensitive to firm performance than total compensation including base salary and bonus, confirming that the Japanese bonus payment 
system makes CEO pay more sensitive to firm performance. ${ }^{21}$ Contrast Tables 6 and 7 to

Tables 3 and 4 respectively confirms that this overall finding is still valid when we study listed firms and unlisted firms separately.

\section{$\underline{\text { V. Conclusions }}$}

This paper has provided the first panel data estimates on the performance sensitivity of CEO's cash compensation in Japan. To do so, we have used unique 10-year panel data on individual CEO's monthly base salary and total annual cash compensation (including both base salary and bonus) of 51 Japanese firms. The most robust determinant of Japanese CEO compensation proves to be ROA (a standard accounting measure of firm profitability). We have found a positive and significant effect on CEO compensation of ROA for all specifications (with and without the year dummy variables and with and without other performance variables). The size of the estimated sensitivity of Japanese CEO's annual cash compensation to ROA are between 1.3 and 1.4 for all firms. It goes up when we consider only listed firms and goes down when considering only unlisted firms. It is hard to compare the size of the estimated sensitivity of cash compensation to ROA that we obtained for Japan to prior estimates elsewhere due to heterogeneous data used by various prior studies. ${ }^{22}$ However, our estimates appear to be in general agreement with prior estimates. ${ }^{23}$ At least our estimates do not support that Japanese corporate governance is unusually defunct with regard to the significance and size of the sensitivity of CEO compensation to accounting measures.

\footnotetext{
${ }^{21}$ Our finding is consistent with earlier work using aggregate compensation data (e.g., Xu, 1977 and Kubo, 2001).

22 Due to such data heterogeneity there are only a limited number of cross-national comparative studies of executive compensation, such as Kato and Rockel (1992a), Kaplan (1994), Abowd and Bognanno (1995), Conyon and Schwalbach (1997), Conyon and Murphy (1999), and Kubo (2001).

${ }^{23}$ For example, Rosen (1990) in reviewing various studies finds the estimated sensitivity of pay to accounting measures are in the $1.0-1.2$ range.
} 
Since our sample includes a relatively small number of listed firms and data on shareholder return (stock market performance measure) are available only for listed firms, our estimated sensitivity of CEO compensation to shareholder return ought to be interpreted with caution. That said, our study tends to support the general perception that Japanese CEO compensation is less sensitive to stock market performance. Specifically, the estimated sensitivity of CEO cash compensation to shareholder return turns out to be less than 0.1 and statistically insignificant (except when the year dummy and all other performance variables are excluded). ${ }^{24}$ As such, our study lends support to some of the earlier studies using aggregate data (e.g., Kaplan, 1994) that point to the relatively weaker role played by stock market measures as compared to accounting performance measures in the determination of compensation for Japanese directors. The evidence is largely consistent with the literature on Japanese corporate governance that tends to stress the role of the main bank and employees in the Japanese corporate governance system.

Finally, we find that the Japanese bonus system makes CEO compensation more sensitive to firm performance. Insofar as CEOs are concerned, bonus does not appear to be a disguised base salary as the literature on the Japanese bonus system often suggests for regular employees.

${ }^{24}$ Rosen (1990) finds the estimated sensitivity of pay to shareholder return is in the $0.10-0.15$. 


\section{References}

Abowd, John, 1990, Does Performance-Based Managerial Compensation Affect Corporate Performance, Industrial and Labor Relations Review 43, s52-73.

Abowd, John and M. Bognanno, 1995, International Differences in Executive and Managerial Compensation, in R. Freeman and L. Katz, eds., Differences and Changes in Wage Structures, Chicago: The University of Chicago Press, 67-103.

Abe, Yukiko, 1997, Chief Executive Turnover and Firm Performance in Japan, Journal of the Japanese and International Economies 11, 2-26.

Ang, James S. and Richard L. Constand, 1997, Compensation and Performance: The Case of Japanese Managers and Directors, Journal of Multinational Financial Management 7, 275-304.

Ahmadjian, Christina, 2001, Changing Japanese Corporate Governance, Center on Japanese Economy and Business Working Paper No. 188, Columbia Business School.

Aoki, Masahiko, 1988, Information, incentives, and bargaining in the Japanese economy (Cambridge University Press, New York and Cambridge).

Aoki, Masahiko and Hugh Patrick, 1994, The Japanese Main Bank System: Its Relevance for Developing and Transforming Economies (Oxford University Press, Oxford).

Brunello, Giorgio, 1991, Bonuses, Wages and Performances in Japan: Evidence from Micro Data, Ricerche Economiche 45, 377-396.

Brunello, Giorgio, Clara Graziano, and Bruno Parigi, 2001, Executive Compensation and Firm Performance in Italy, International Journal of Industrial Organization 19, 133-61.

Conyon, M. and J. Schwalbach, 1997, European Differences in Executive Pay and Corporate Governance, Mimeo, Warwick Business School.

Conyon, M. and K.J. Murphy, 1999, The Prince and the Pauper, Mimeo, Marshall School of Business, The University of Southern California.

Eriksson, Tor, 1999, Executive Compensation and Tournament Theory, Journal of Labor Economics 17, 262-280.

Eriksson, Tor, 2003, Managerial Pay and Executive Turnover in the Czech and Slovak Republics, Mimeo, Aarhus Business School.

Freeman, Richard B. and Martin L. Weitzman, 1987, Bonuses and Employment in Japan, Journal of the Japanese and International Economies 1, 168-194.

Fukao, M. 1995, Financial Integration, Corporate Governance, and the Performance of Multinational Companies (The Brookings Institution, Washington, D.C.). 
Gibbons, Robert and Michael Waldman, 1999, Careers in Organizations: Theory and Evidence, in Orley Ashenfelter and David Card (eds.), Handbook of Labor Economics, Vol. 3 (North Holland, Amsterdam) 2373-2437.

Hart, Robert A. and Seiichi Kawasaki, 1999, Work and Pay in Japan (Cambridge University Press, Cambridge).

Hashimoto, Masahori, 1990, The Japanese Labor Market in a Comparative Perspective with the United States: A Transaction-Cost Interpretation (Upjohn Institute, Kalamazoo).

Hoshi, T., A. Kashyap, and D. Scharfstein, 1990, The role of banks in reducing the costs of financial distress in Japan, Journal of Financial Economics 27, 67-88.

Hoshi, T., A. Kashyap, and D. Scharfstein, 1991, Corporate structure, liquidity, and investment: evidence from Japanese industrial groups, Quarterly Journal of Economics 106, 33-60.

Joh, Sung Wook, 1999, Strategic Managerial Incentive Compensation in Japan: Relative Performance Evaluation and Product Market Collusion, Review of Economics and Statistics 81, 303-13.

Kaplan, S., 1994, Top executive rewards and firm performance: A comparison of Japan and the U.S., Journal of Political Economy 102, 510-546.

Kaplan, S. and Bernadette A. Minton, 1994, Appointments of outsiders to Japanese boards: determinants and implications for managers, Journal of Financial Economics 36, 225-58.

Kato, Takao and Mark Rockel, 1992a, Experiences, credentials and compensation in the Japanese and U.S. managerial labor markets: evidence from new micro data, Journal of the Japanese and International Economies 6, 30-51.

Kato, Takao and Mark Rockel, 1992b, The Importance of Company Breeding in the U.S. and Japanese Managerial Labor Markets: A Statistical Comparison, Japan and the World Economy 4, 39-45

Kato, Takao. 1997, Chief Executive Compensation and Corporate Groups in Japan: New Evidence from Micro Data," International Journal of Industrial Organization 15, 455-67.

Kubo, Katsuyuki, 2001, The Determinants of Executive Compensation in Japan and the U.K.: Agency Hypothesis or Joint Determination hypothesis?, CEI Working Paper Series, No. 2001-2, Hitotsubashi University.

Leonard, Jonathan, 1999, Executive Pay and Firm Performance, Industrial and Labor Relations Review 43, s13-29.

Matsumoto, K., 1991, The Rise of the Japanese Corporate System (Kegan Paul International). 
Montalvo, Jose G., and Yishay Yafeh, 1994, A microeconometric analysis of technology transfer: the case of licensing agreements of Japanese firms, International Journal of Industrial Organization 12, 227-44.

Morck, Randall and Masao, Nakamura, 1999, Banks and Corporate Control in Japan, Journal of Finance 54, 319-39.

Murphy, Kevin, J., 1998, Executive Compensation, in Orley Ashenfelter and David Card (eds.), Handbook of Labor Economics, Vol. 3 (North Holland, Amsterdam) 2485-2563.

Nagaoka, Sadao, 2001, Determinants of the Introduction of Stock Options by Japanese Firms: Analysis from Incentive and Selection Perspectives, Mimeo, Institute of Innovation Research, Hitotsubashi University.

Ohashi, Isao, 1989, On the Determinants of Bonuses and Basic Wages in Large Japanese Firms, Journal of the Japanese and International Economies 3, 451-479.

Romu Gyosei Kenkyu Jo, 1984, Rosei Jiho, No. 2718, 70-71.

Romu Gyosei Kenkyu Jo, 1988, Rosei Jiho, No. 2905, 2-45.

Rosen, Sherwin, 1990, Contracts and the Market For Executives, NBER Working Paper, No. 3542, 1990.

Sheard, Paul, 1989, The Main Bank System and Corporate Monitoring and Control in Japan, Journal of Economic Behavior and Organization 11, 399-422.

Weinstein, David E., and Yishay Yafeh, 1995, Japan's Corporate Groups: Collusive or Competitive? An Empirical Investigation of Keiretsu Behavior, Journal of Industrial Economics 43, 359-76.

Weinstein, David E., and Yishay Yafeh, 1998, On the Costs of a Bank-Centered Financial System: Evidence from the Changing Main Bank Relations in Japan, Journal of Finance 53, 635-72

$\mathrm{Xu}$, Peng, 1997, Executive Salaries as Tournament Prizes and Executive Bonuses as Managerial Incentives in Japan, Journal of the Japanese and International Economies 11, 319-46. 
Table1 Summary statistics

\begin{tabular}{|c|c|c|c|c|c|c|c|c|c|c|}
\hline \multirow[b]{2}{*}{ Variable } & \multirow[b]{2}{*}{ Definitions } & \multicolumn{3}{|c|}{ All firms } & \multicolumn{3}{|c|}{ Listed firms } & \multicolumn{3}{|c|}{ Unlisted firms } \\
\hline & & Obs & Mean & Std. Dev. & Obs & Mean & Std. Dev. & Obs & Mean & Std. Dev. \\
\hline DAPAY & change in apay from Year $t-1$ to Year $t$ & 357 & 47.62945 & 515.7409 & \begin{tabular}{|l|l|}
9 & 126 \\
\end{tabular} & $6 \quad 95.26443$ & $3 \quad 370.8566$ & $6 \quad 231$ & 21.64674 & 578.823 \\
\hline DMPAY & change in mpay from Year $\mathrm{t}-1$ to Year $\mathrm{t}$ & 367 & 3.878797 & \begin{tabular}{|l|l|}
7 & 36.9768 \\
\end{tabular} & \begin{tabular}{|l|l|}
8 & 132 \\
\end{tabular} & 26.309588 & $8 \quad 22.56335$ & 5235 & 2.513417 & 42.99249 \\
\hline SALES & Sales in millions of 2000 yen & 455 & 43507.17 & \begin{tabular}{|l|l|}
7 & 51955.58 \\
\end{tabular} & \begin{tabular}{|l|l|}
8 & 190 \\
\end{tabular} & 061793.56 & $6 \quad 55987.22$ & 265 & 30396.17 & 44551.58 \\
\hline ROA & Return On Assets (profit/assets) & 446 & 0.043735 & 0.045223 & \begin{tabular}{|l|l|}
$3 \quad 181$ \\
\end{tabular} & 10.046875 & $5 \quad 0.033183$ & $3 \quad 265$ & 0.04159 & 0.051819 \\
\hline DROA & change in roa from Year t-1 to Year $t$ & 397 & -0.00073 & 0.029704 & \begin{tabular}{|l|l|}
$4 \quad 162$ \\
\end{tabular} & $2-0.00187$ & $7 \quad 0.021827$ & $7 \quad 235$ & 5.0000656 & 0.034115 \\
\hline NEGPROF & 1 if the firm's profit is negative, 0 otherwise. & 446 & 0.078475 & 0.26922 & \begin{tabular}{|l|l|}
2 & 181 \\
\end{tabular} & 10.066298 & 8.249493 & 3265 & 0.086793 & 0.282063 \\
\hline EMPLOYEE & Number of employees & 510 & 735.6078 & \begin{tabular}{|l|l|} 
& 1084.816 \\
\end{tabular} & \begin{tabular}{|l|l|}
$6 \quad 190$ \\
\end{tabular} & \begin{tabular}{l|l|}
0 & 1354.842 \\
\end{tabular} & $2 \quad 1466.261$ & 320 & 367.9375 & 489.8823 \\
\hline ROR & Shareholder Return & & & & 162 & 20.049873 & $3 \quad 0.321382$ & & & \\
\hline
\end{tabular}

Source: A private survey conducted annually since 1986 by a compensation consulting firm.

Notes: The sample includes 18 listed and 33 unlisted firms from 1986-1995. All variables are adjusted by CPI(FY2000=100). 
Table 2 Determinants of CEO's Annual Cash Compensation (All firms)

\begin{tabular}{|c|c|c|c|c|c|c|c|c|}
\hline & Eq. (2) & Eq. (2)' & Eq. (3) & Eq. (3)' & Eq. (4) & Eq. (4)' & Eq. (5) & Eq. (5)' \\
\hline DROA & 1.415 & $\begin{array}{c}1.391 \\
028 * *)\end{array}$ & & & & & 1.261 & 1.256 \\
\hline NEGPROF & $\left(0.235^{* * *}\right)$ & $(0.238 * * *)$ & $\begin{array}{c}-0.09 \\
(0.030 * * *)\end{array}$ & $\begin{array}{c}-0.09 \\
\left(0.031^{* * *}\right)\end{array}$ & & & $\begin{array}{c}(0.253 * * *) \\
-0.06 \\
(0.030 * *)\end{array}$ & $\begin{array}{c}\left(0.257^{* * *}\right) \\
-0.06 \\
(0.030 * *)\end{array}$ \\
\hline GSALES & & & & & $\begin{array}{c}0.149 \\
(0.052 * * *)\end{array}$ & $\begin{array}{c}0.141 \\
\left(0.056^{* *}\right)\end{array}$ & $\begin{array}{c}0.044 \\
(0.064)\end{array}$ & $\begin{array}{c}0.041 \\
(0.070)\end{array}$ \\
\hline year dummy & & Yes & & Yes & & Yes & & Yes \\
\hline _cons & $\begin{array}{c}0.006 \\
(0.007)\end{array}$ & $\begin{array}{c}0.041 \\
\left(0.023^{* *}\right)\end{array}$ & $\begin{array}{c}0.011 \\
(0.008)\end{array}$ & $\begin{array}{c}0.043 \\
\left(0.026^{* *}\right)\end{array}$ & $\begin{array}{c}0.001 \\
(0.007)\end{array}$ & $\begin{array}{c}0.042 \\
(0.024 * *)\end{array}$ & $\begin{array}{c}0.010 \\
(0.008)\end{array}$ & $\begin{array}{c}0.043 \\
(0.023 * *)\end{array}$ \\
\hline Obs. & 303 & 303 & 308 & 308 & 311 & 311 & 303 & 303 \\
\hline $\mathrm{R}^{2}$ & 0.1072 & 0.1346 & 0.0345 & 0.0613 & 0.0252 & 0.0502 & 0.1276 & 0.1508 \\
\hline
\end{tabular}

Source: A private survey conducted annually since 1986 by a compensation consulting firm.

Notes: The sample includes 18 listed and 33 unlisted firms from 1986-1995. All variables are adjusted by CPI(FY2000=100). Standard errors are in parentheses.

***significant at the 1 percent level. **significant at the 5 percent level; *significant at the 10 percent level 
Table 3 Determinants of CEO's Annual Cash Compensation (Listed firms)

\begin{tabular}{|c|c|c|c|c|c|c|c|c|c|c|}
\hline \multicolumn{11}{|c|}{ Dependent variable $=\Delta \ln (\mathrm{APAY})$} \\
\hline & Eq. (2) & Eq. (2) & Eq. (3) & Eq. (3)' & Eq. (4) & Eq. (4)' & Eq. (6) & Eq. (6)' & Eq. (7) & Eq. (7)' \\
\hline DROA & $\begin{array}{c}2.150 \\
(0.437 * * *)\end{array}$ & $\begin{array}{c}1.633 \\
(0488 * * *)\end{array}$ & & & & & & & $\begin{array}{c}1.880 \\
(0449 * * *)\end{array}$ & $\begin{array}{c}1.452 \\
0.494 * * *)\end{array}$ \\
\hline NEGPROF & & & $\begin{array}{c}-0.10 \\
\left(0.041^{* *}\right)\end{array}$ & $\begin{array}{c}-0.09 \\
\left(0.041^{* *}\right)\end{array}$ & & & & & $\begin{array}{c}-0.07 \\
\left(0.039^{*}\right)\end{array}$ & $\begin{array}{c}-0.08 \\
(0.040 *)\end{array}$ \\
\hline GSALES & & & & & $\begin{array}{c}0.069 \\
(0.066)\end{array}$ & $\begin{array}{c}0.070 \\
(0.070)\end{array}$ & & & $\begin{array}{c}0.033 \\
(0.094)\end{array}$ & $\begin{array}{c}0.061 \\
(0.113)\end{array}$ \\
\hline ROR & & & & & & & $\begin{array}{c}0.092 \\
(0.032 * * *)\end{array}$ & $\begin{array}{c}0.070 \\
(0.044)\end{array}$ & $\begin{array}{c}0.041 \\
(0.033)\end{array}$ & $\begin{array}{c}0.022 \\
(0.046)\end{array}$ \\
\hline year dummy & & Yes & & Yes & & Yes & & Yes & & yes \\
\hline cons & $\begin{array}{c}0.011 \\
(0.009)\end{array}$ & $\begin{array}{c}-0.00 \\
(0.033)\end{array}$ & $\begin{array}{c}0.016 \\
(0.010)\end{array}$ & $\begin{array}{c}-0.01 \\
(0.034)\end{array}$ & $\begin{array}{c}0.010 \\
(0.010)\end{array}$ & $\begin{array}{c}0.015 \\
(0.033)\end{array}$ & $\begin{array}{c}0.004 \\
(0.010)\end{array}$ & $\begin{array}{c}-0.03 \\
(0.033)\end{array}$ & $\begin{array}{c}0.013 \\
(0.010)\end{array}$ & $\begin{array}{c}-0.01 \\
(0.032)\end{array}$ \\
\hline $\begin{array}{l}\text { Obs. } \\
\mathrm{R}^{2}\end{array}$ & $\begin{array}{c}118 \\
0.1721\end{array}$ & $\begin{array}{c}118 \\
0.2454\end{array}$ & $\begin{array}{c}118 \\
0.0503\end{array}$ & $\begin{array}{c}118 \\
0.2107\end{array}$ & $\begin{array}{c}126 \\
0.0089\end{array}$ & $\begin{array}{c}126 \\
0.1531\end{array}$ & $\begin{array}{c}118 \\
0.0637\end{array}$ & $\begin{array}{c}118 \\
0.1862\end{array}$ & $\begin{array}{c}118 \\
0.2210\end{array}$ & $\begin{array}{c}118 \\
0.2832\end{array}$ \\
\hline
\end{tabular}

Source: A private survey conducted annually since 1986 by a compensation consulting firm.

Notes: The sample includes 18 listed firms from 1986-1995. All variables are adjusted by CPI(FY2000=100).

Standard errors are in parentheses.

*** significant at the 1 percent level. **significant at the 5 percent level; *significant at the 10 percent level 
Table 4 Determinants of CEO's Annual Cash Compensation (Unlisted firms)

\begin{tabular}{|c|c|c|c|c|c|c|c|c|}
\hline \multicolumn{9}{|c|}{ Dependent variable $=\Delta \ln ($ APAY $)$} \\
\hline & Eq. (2) & Eq. (2)' & Eq. (3) & Eq. (3)' & Eq. (4) & Eq. (4)' & Eq. (5) & Eq. (5)' \\
\hline \multirow[t]{2}{*}{$\overline{\mathrm{DROA}}$} & 1.240 & 1.317 & & & & & 1.077 & 1.115 \\
\hline & $\left(0.288^{* * *}\right)$ & $\left.0.293^{* * *}\right)$ & & & & & $\left(0.323^{* * *}\right)$ & $\left(0.335^{* * *}\right)$ \\
\hline \multirow[t]{2}{*}{ NEGPROF } & & & -0.09 & -0.09 & & & -0.06 & -0.05 \\
\hline & & & $(0.041 * *)$ & $(0.043 * *)$ & & & $(0.042)$ & $(0.043)$ \\
\hline \multirow[t]{2}{*}{ GSALES } & & & & & 0.215 & 0.248 & 0.050 & 0.072 \\
\hline & & & & & $(0.078 * * *)$ & $(0.084 * * *)$ & $(0.088)$ & $(0.094)$ \\
\hline year dummy & & Yes & & Yes & & Yes & & yes \\
\hline \multirow[t]{2}{*}{ cons } & 0.002 & 0.054 & 0.008 & 0.047 & -0.00 & 0.043 & 0.006 & 0.051 \\
\hline & $(0.010)$ & $(0.033)$ & $(0.011)$ & $(0.034)$ & $(0.011)$ & $(0.034)$ & $(0.011)$ & $(0.033)$ \\
\hline Obs. & 185 & 185 & 190 & 190 & 185 & 185 & 185 & 185 \\
\hline $\mathrm{R}^{2}$ & 0.0919 & 0.1358 & 0.0284 & 0.0608 & 0.0395 & 0.0812 & 0.1072 & 0.1481 \\
\hline
\end{tabular}

Source: A private survey conducted annually since 1986 by a compensation consulting firm.

Notes: The sample includes 33 unlisted firms from 1986-1995. All variables are adjusted by CPI(FY2000=100).

Standard errors are in parentheses.

***significant at the 1 percent level. **significant at the 5 percent level; *significant at the 10 percent level 
Table 5 Determinants of CEO's Monthly Base Salary (All firms)

\begin{tabular}{lcccccccc}
\hline \multicolumn{7}{c}{ Dependent variable= $\Delta \ln ($ MPAY) } \\
\hline DROA & Eq. (2) & Eq. (2) & Eq. (3) & Eq. (3) & Eq. (4) & Eq. (4) & Eq. (5) & Eq. (5)' \\
& 0.917 & 0.867 & & & & & 0.836 & 0.837 \\
NEGPROF & $\left(0.214^{* * *}\right)$ & $\left(0.216^{* * *}\right)$ & & & & & $\left(0.231^{* * *}\right)$ & $\left(0.234^{* * *}\right)$ \\
& & & -0.06 & -0.05 & & & -0.04 & -0.04 \\
GSALES & & & $\left(0.025^{* *}\right)$ & $\left(0.026^{* *}\right)$ & & & $\left(0.026^{* *}\right)$ & $(0.027)$ \\
& & & & & 0.092 & 0.072 & 0.013 & -0.01 \\
year dummy & & Yes & & & $\left(0.047^{* *}\right)$ & $(0.050)$ & $(0.059)$ & $(0.063)$ \\
cons & 0.010 & 0.046 & 0.013 & 0.020 & 0.007 & 0.046 & 0.013 & 0.048 \\
& $(0.006)$ & $\left(0.021^{* *}\right)$ & $\left(0.007^{* *}\right)$ & $(0.023)$ & $(0.006)$ & $\left(0.021^{* *}\right)$ & $\left(0.007^{* *}\right)$ & $\left(0.021^{* *}\right)$ \\
\hline Obs. & 313 & 313 & 318 & 318 & 321 & 321 & 313 & 313 \\
$\mathrm{R}^{2}$ & 0.0554 & 0.0867 & 0.0202 & 0.0517 & 0.0119 & 0.0411 & 0.0675 & 0.0947 \\
\hline
\end{tabular}

Source: A private survey conducted annually since 1986 by a compensation consulting firm.

Notes: The sample includes 18 listed and 33 unlisted firms from 1986-1995. All variables are adjusted by CPI(FY2000=100). Standard errors are in parentheses.

***significant at the 1 percent level. **significant at the 5 percent level; *significant at the 10 percent level 
Table 6 Determinants of CEO's Monthly Base Salary (Listed firms)

Dependent variable $=\Delta \ln (\mathrm{MPAY})$

\begin{tabular}{|c|c|c|c|c|c|c|c|c|c|c|}
\hline & Eq. (2) & Eq. (2)' & Eq. (3) & Eq. (3) & Eq. (4) & Eq. (4)' & Eq. (6) & Eq. (6) & Eq. (7) & Eq. (7)' \\
\hline DROA & $\begin{array}{c}1.643 \\
(0.386 * * *)\end{array}$ & $\begin{array}{c}1.294 \\
(0.423 * * *)\end{array}$ & & & & & & & $\begin{array}{c}1.494 \\
(0.402 * * *)\end{array}$ & $\begin{array}{c}1.169 \\
0.431 * * *)\end{array}$ \\
\hline NEGPROF & & & $\begin{array}{c}-0.07 \\
\left(0.036^{* *}\right)\end{array}$ & $\begin{array}{c}-0.06 \\
(0.036 * *)\end{array}$ & & & & & $\begin{array}{c}-0.06 \\
\left(0.035^{*}\right)\end{array}$ & $\begin{array}{c}-0.05 \\
(0.036)\end{array}$ \\
\hline GSALES & & & & & $\begin{array}{c}0.046 \\
(0.057)\end{array}$ & $\begin{array}{c}0.040 \\
(0.061)\end{array}$ & & & $\begin{array}{c}0.003 \\
(0.083)\end{array}$ & $\begin{array}{c}-0.04 \\
(0.097)\end{array}$ \\
\hline ROR & & & & & & & $\begin{array}{c}0.060 \\
(0.028 * *)\end{array}$ & $\begin{array}{c}0.064 \\
(0.038 * *)\end{array}$ & $\begin{array}{c}0.021 \\
(0.029)\end{array}$ & $\begin{array}{c}0.039 \\
(0.040)\end{array}$ \\
\hline $\begin{array}{l}\text { year dummy } \\
\text { cons }\end{array}$ & $\begin{array}{c}0.014 \\
\left(0.008^{* *}\right) \\
\end{array}$ & $\begin{array}{c}\text { Yes } \\
-0.01 \\
(0.028) \\
\end{array}$ & $\begin{array}{c}0.017 \\
(0.009 * *) \\
\end{array}$ & $\begin{array}{c}\text { Yes } \\
-0.01 \\
(0.028) \\
\end{array}$ & $\begin{array}{c}0.012 \\
(0.008) \\
\end{array}$ & $\begin{array}{c}\text { Yes } \\
-0.01 \\
(0.028) \\
\end{array}$ & $\begin{array}{c}0.009 \\
(0.009) \\
\end{array}$ & $\begin{array}{c}\text { Yes } \\
0.002 \\
(0.029) \\
\end{array}$ & $\begin{array}{c}0.016 \\
(0.009 *) \\
\end{array}$ & $\begin{array}{c}\text { yes } \\
0.019 \\
(0.029) \\
\end{array}$ \\
\hline $\begin{array}{l}\text { Obs. } \\
\mathrm{R}^{2}\end{array}$ & $\begin{array}{c}124 \\
0.1291\end{array}$ & $\begin{array}{c}124 \\
0.2182\end{array}$ & $\begin{array}{c}124 \\
0.0359\end{array}$ & $\begin{array}{c}124 \\
0.1781\end{array}$ & $\begin{array}{c}132 \\
0.0050\end{array}$ & $\begin{array}{c}132 \\
0.1422\end{array}$ & $\begin{array}{c}124 \\
0.0346\end{array}$ & $\begin{array}{c}124 \\
0.1742\end{array}$ & $\begin{array}{c}124 \\
0.1585\end{array}$ & $\begin{array}{c}124 \\
0.2432\end{array}$ \\
\hline
\end{tabular}

Source: A private survey conducted annually since 1986 by a compensation consulting firm.

Notes: The sample includes 18 listed firms from 1986-1995. All variables are adjusted by CPI(FY2000=100).

Standard errors are in parentheses.

***significant at the 1 percent level. **significant at the 5 percent level; *significant at the 10 percent level 
Table 7 Determinants of CEO's Monthly Base Salary (Unlisted firms)

Dependent variable $=\Delta \ln (\mathrm{MPAY})$

\begin{tabular}{|c|c|c|c|c|c|c|c|c|}
\hline & Eq. (2) & Eq. (2)' & Eq. (3) & Eq. (3)' & Eq. (4) & Eq. (4)' & Eq. (5) & Eq. (5)' \\
\hline \multirow[t]{2}{*}{ DROA } & 0.744 & 0.784 & & & & & 0.645 & 0.697 \\
\hline & $(0.266 * * *$ & $0.271 * * *)$ & & & & & $(0.299 * *)$ & $(0.311 * *)$ \\
\hline \multirow[t]{2}{*}{ NEGPROF } & & & -0.05 & -0.05 & & & -0.04 & -0.03 \\
\hline & & & $(0.034 * *)$ & $(0.036)$ & & & $(0.036)$ & $(0.038)$ \\
\hline \multirow[t]{2}{*}{ GSALES } & & & & & 0.129 & 0.133 & 0.026 & 0.023 \\
\hline & & & & & $(0.070 * *)$ & $(0.076 * *)$ & $(0.081)$ & $(0.088)$ \\
\hline \multirow{3}{*}{$\begin{array}{l}\text { year dummy } \\
\text { _cons }\end{array}$} & & Yes & & Yes & & Yes & & yes \\
\hline & 0.007 & 0.040 & 0.012 & 0.056 & 0.004 & 0.028 & 0.010 & 0.040 \\
\hline & $(0.009)$ & $(0.034)$ & $(0.010)$ & $(0.030 * *)$ & $(0.009)$ & $(0.035)$ & $(0.010)$ & $(0.035)$ \\
\hline Obs. & 189 & 189 & 194 & 194 & 189 & 189 & 189 & 189 \\
\hline $\mathrm{R}^{2}$ & 0.0452 & 0.1286 & 0.0199 & 0.0969 & 0.0228 & 0.1031 & 0.0637 & 0.1426 \\
\hline
\end{tabular}

Source: A private survey conducted annually since 1986 by a compensation consulting firm.

Notes: The sample includes 33 unlisted firms from 1986-1995. All variables are adjusted by CPI(FY2000=100).

Standard errors are in parentheses. $\quad * * *$ significant at the 1 percent level. **significant at the 5 percent level; *significant at the 10 percent level. 
Figure 1 Comparing ROA between the population and our sample

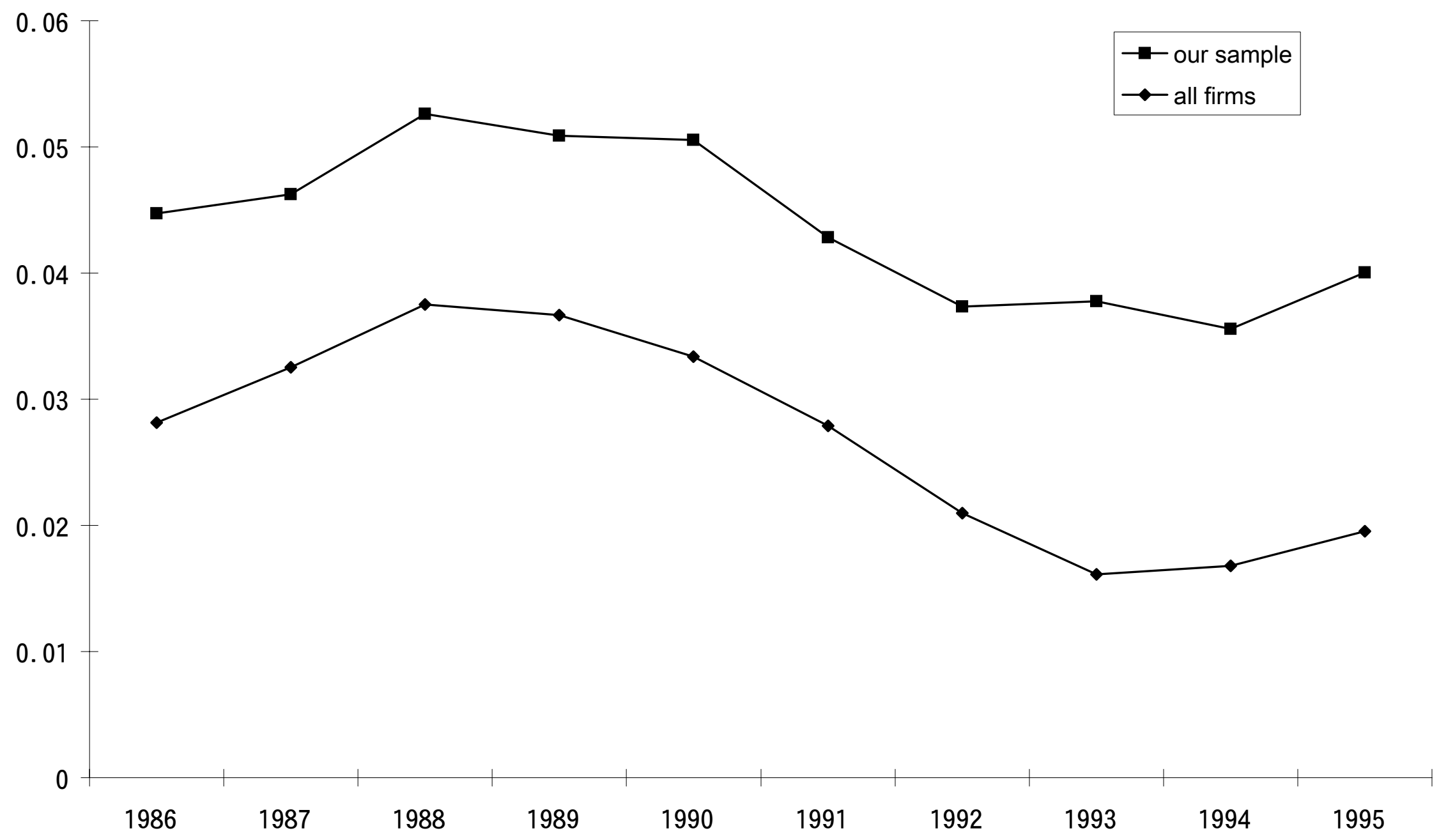


Figure 2 Comparing Shareholder returns between the population and our sample

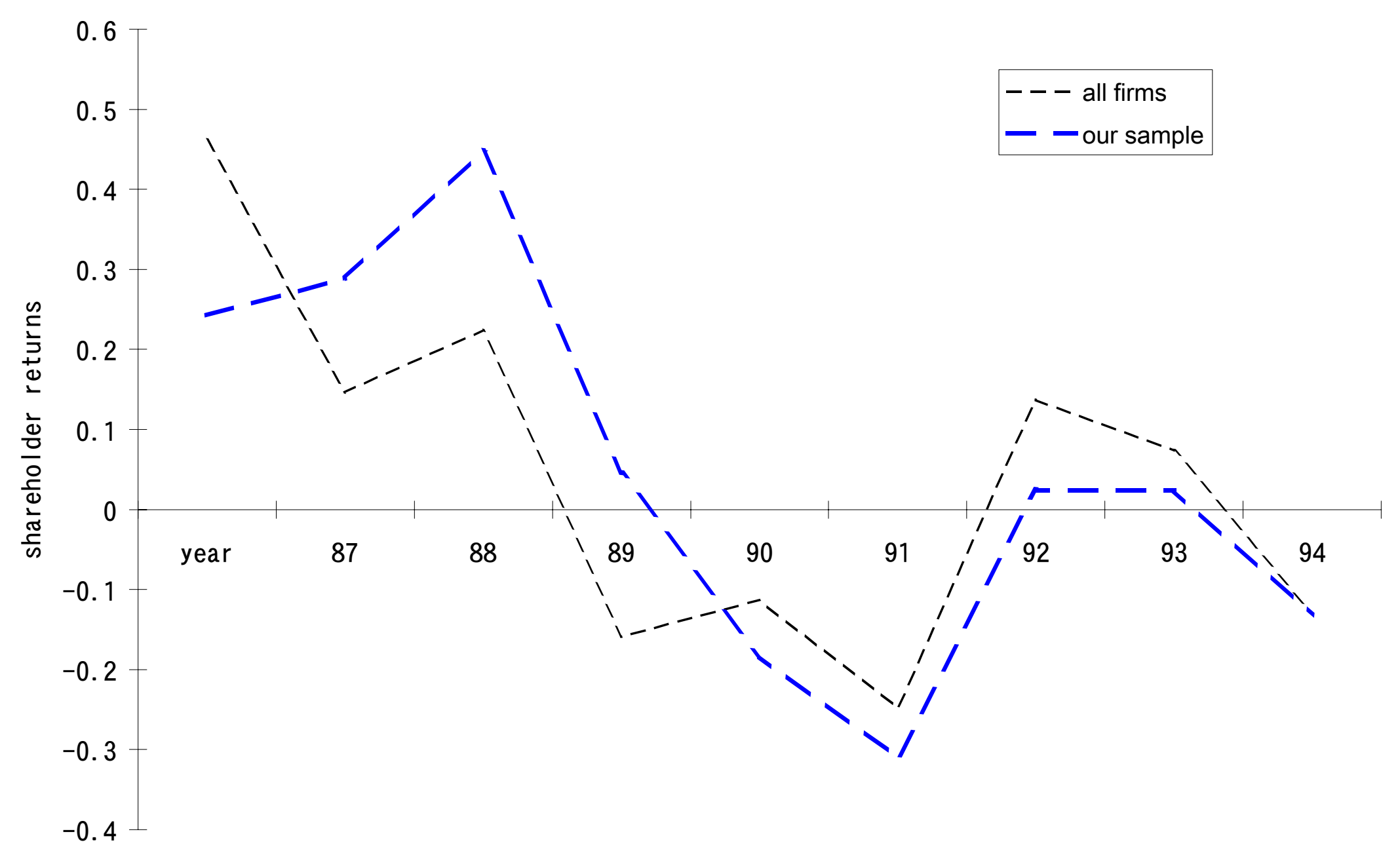

year 